\title{
ACTIVE LEGITIMIZATION IN CONSTITUTIONAL PROCEEDINGS: THE SPANISH CASE1
}

\author{
AMELIA PASCUAL MEDRANO \\ Profesora Titular de Derecho constitucional \\ Universidad de La Rioja
}

\section{SUMARIO}

I. INTRODUCTION. II. LEGAL SOURCES OF LEGITIMIZATION BEFORE THE CONSTITUTIONAL COURT. III. RULES OF ACTIVE LEGITIMIZATION IN CONSTITUTIONAL ROCEEDINGS: 1. Individuals. 2. Political agents. 3. Courts. IV. SENSE AND CONSEQUENCES OF THE LEGITIMIZATION RULES DESCRIBED.

\section{RESUMEN}

This article will examine access to the Spanish Constitutional Court. That court is the supreme interpreter of the constitution and has the exclusive authority to declare legislation unconstitutional. Two principal avenues are available to secure such a declaration-the "unconstitutionality appeal" and the "submission for unconstitutionality." The first is available to specified political officials; the latter to judges who encounter laws of doubtful constitutionality in the course of litigation. The submission for unconstitutionality thus effects something of a rapprochement between the concentrated system of constitutional review and the diffuse American approach. In addition to these procedures, individuals may invoke constitutional jurisdiction but only through an "appeal for legal protection for constitutional rights." \footnotetext{
2002.

${ }^{1}$ Spanish report for the $26^{\text {th }}$ International Congress of Comparative Law. Brisbane (Australia), July,
} 


\section{INTRODUCTION}

First of all, and before going straight into the precise subject which is the object of this report, it may be useful, in my opinion, to describe, at least summarily, the fundamental features of the Spanish model of Constitutional Law.

1-The death of General Franco in 1975 opened a transition period in the Spanish politics which culminated in the approval of the 1978 Constitution and, thus, in the incorporation of Spain, after 40 years of dictatorship, into a democratic regime.

2-This is the first Spanish Constitution (hereinafter, S.C.) which recognizes in an explicit way the normative and binding nature of the Constitutional instrument (Section 9.1: "The citizens and the public powers shall be subject to the Constitution and the rest of the legal system" ${ }^{2}$. Besides, the Constitution is not only an effective legal instrument, but as the above mentioned disposition implies, the paramount legal instrument. The Spanish Constitutional Court has held, in this sense, that "the Constitution, far from being a mere catalogue of principles not directly binding and enforceable until legally developed, is the supreme norm of our system and, therefore, both the citizens and the legal powers, and thus, also the judges and magistrates of the judiciary, are subject to it» (S.C.C. 16/1982, $28^{\text {th }}$ April, Legal Grounds, $1^{\circ}$ ).

3-Obviously, the supremacy of the Constitution, if it is not intended to be a purely rhetorical principle, leads to the need of establishing control mechanisms which ensure their enforcement. Therefore, the 1978 Constitution, in Title IX ("On the Constitutional Court"), creates a model of Constitutional justice for Spain which, apart from the precedent of the Court of Constitutional Guarantees created by the Constitution of the $2^{\text {nd }}$ Spanish Republic (1931), follows the 1947 Italian Constitution somewhat, but above all, the 1949 Fundamental Law of Bonn.

4-From all the preceding facts, the one conclussion to be drawn already at this point is that the Spanish Constitution has basically chosen a model of concentrated Constitutional jurisdiction: only the Constitutional Court (hereinafter, C.C.) can declare unconstitutional the legislative decrees.

5-The Spanish Constitutional Court is a Constitutional body which is only subject to the Constitution and its own organic Law (Organic Law 2/1979, $3^{\text {rd }}$ October, from the Constitutional Court, hereinafter, O.L.C.C... $)^{3}$. Its composition was foreseen in the Constitution itself (Section 159.1): "The Constitutional Court shall be composed of 12 members appointed by the King, out of them, four at the instance of the Congress by a majority of three fifths, four at the instance of the Senate, by an identical majority, two at the instance of the Government and two at the instance of the General Board of the Judiciary".

2 On this subject, see E. García de Enterría, La Constitución como norma y el Tribunal Constitucional, $3^{\mathrm{a}}$ ed., Civitas, Madrid, 1991.

3 Section 165 of the S.C.: "The operation of the Constitutional Court, the proceedings before it and the eligibility conditions to enforce actions shall be regulated by an organic law". 
6-The C.C. is the supreme interpreter of the Constitution (Section 1 of the O.L.C.C.) and, as we have already said, it was granted the monopoly of declaring unconstitutional the legal dispositions. However, this does not mean at all that it is the only body which must apply and interpret the Constitution. The Constitution is binding for all the citizens and for all the authorities and therefore, both ordinary judges and courts must also interpret and apply the Constitution ${ }^{4}$.

7-The S.C.C. includes a wide range of competencies:

a) It monitors the Constitutional character of the laws and legislative decrees of the State and the Autonomous Communities through the unconstitutionality appeal (recurso de inconstitucionalidad) (direct appeal or abstract control) and through the submission for unconstitutionality (cuestión de inconstitucionalidad) (indirect appeal or concrete control). The unconstitutionality appeal can be lodged by several bodies or parts of bodies [see Section 162.1 a) S.C.: the Prime Minister, the Ombudsman, fifty Deputes, fifty Senators, the collegial executive bodies of the Autonomous Communities and their assemblies]. The unconstitutionality appeal must be lodged, generally speaking, within three months from the date of issue of the instrument, disposition or legislative decree in question. The submission for unconstitutionality must be lodged before the Constitutional Court when a legal body considers, in the framework of a particular proceeding, that a legislative decree applicable to the case and on which the decision drawn might be unconstitutional (Section 163 S.C.) ${ }^{5}$.

b) It guarantees the fundamental public rights through the appeal for legal protection (recurso de amparo). This is an extraordinary appeal aimed at protecting particular rights granted by the Constitution (Section 53.2. S.C.). It can be lodged by any individual or legal person with a legitimate interest, as well as by the Ombudsman and the Attorney General's Office (Section 162.1 b) S.C.), against the infringement of those rights by any authority once all the ordinary legal proceedings have been exhausted (except in the case of the non legislative decrees from the legislature, where the appeal can be directly lodged).

c) It rules on the Constitutional disputes. These can be of three kinds: disputes of competence (conflicto de competencias) between the State and the Autonomous Communities (hereinafter, AA.CC.), or amongst the AA.CC. themselves [Section 16.1 c) S.C.]; disputes between Constitutional bodies of the State; and disputes for the defence of the local autonomy.

Disputes of competence can be both positive and negative. In the positive ones, a single AA.CC. or two AA.CC. conflict for the same competence. Positive conflicts can be lodged by the Government when it considers that a ruling or a disposition of an A.C.

\footnotetext{
${ }^{4}$ However, in connection with the role of the C.C. as "supreme interpreter of the Constitution", its interpretation in the resolution of any kind of constitutional proceeding, links both the judges and the courts of justice. In this sense, Section 5.1 of the Organic Law of the Judicature establishes that the judges and courts "shall interpret and apply the legislation and regulations according to the Constitutional rules and principles, pursuant the interpretation arising from the rulings of the Constitutional Court in any kind of proceeding".

5 The submission of unconstitutionality implies therefore a rapprochement of our concentrated system of control to the diffuse American one.
} 
infringes the jurisdictional order established in the Constitution, in the Autonomous Statutes or in the corresponding Organic Laws; and, in the same way, by the superior executive body of an A.C. when it considers that a ruling, resolution or action of the State infringes the jurisdictional order, provided that it affects its own range of autonomy (Sections 62 and 63 of the O.L.C.C.). As for the negative disputes (very rarely used), both parties reject being the holder of the competence in question. Negative conflicts can be lodged by any individual or legal person, if his/its claim has not been settled by the State nor by the AA.CC. on the grounds that both consider that they are not incumbent (Section 68 of the O.L.C.C.). Furthermore, the State Government can lodge a negative dispute when it has urged the Government of an A.C. to enforce the powers of a given competence and this request has not been met on the basis that the Autonomous Government considers that it lacks jurisdiction (Section 71 of the O.L.C.C.).

The disputes between Constitutional bodies of the State are not foreseen in the S.C. It was the O.L.C.C. which granted the C.C. this competence on the basis of Section $161.1 \mathrm{~d})$ of the Constitution ${ }^{6}$. They have rarely been used and are aimed at solving disputes arising between the Government and the Congress, the Senate or the General Board of the Judiciary; or amongst any of them [Section 59.1 c) of the O.L.C.C.], as regards the powers or competencies assigned by the Constitution or by Organic Laws (Section 73 O.L.C.C.).

The disputes for the defence of the local autonomy (introduced by the O.L. 7/1999 amending the O.L.C.C.) can be lodged by the local entities when State or autonomous legislative decrees damage the local autonomy guaranteed by the Constitution (Sections 75 bis and 75 ter O.L.C.C.).

d) It settles the challenging issues the Government can lodge against non legislative decrees and resolutions of the AA.CC. allegedly unconstitutional (Section 161.2 S.C.).

e) At the request of the Government or any of the Chambers of the legislative assembly (Cortes Generales), it considers a possible inconsistency between the Constitution and the covenants of the definitive text of an international treaty the State has not still agreed (Section 95 S.C.).

\section{LEGAL SOURCES OF LEGITIMIZATION BEFORE THE CONSTITUTIONAL COURT.}

As we have just seen, it has been the Constitution itself which has dealt with the issue of the legitimization in Constitutional proceedings to a great extent (Sections 95.2,

\footnotetext{
6 Section 161 of the S.C. foresees that: "1. The Constitutional Court shall have jurisdiction over the whole territory of Spain and can hear: a) unconstitutionality appeals against laws and legislative decrees $\ldots$ b) appeals for legal protection against infringements of the rights included in Section 53.2 of this Constitution, in the cases and forms established by the law. c) the disputes of competence between the State and the Autonomous Communities or amongst the Autonomous Communities. d) the rest of the issues attributed to the Constitution or to the organic laws".
} 
161.2, 162, and 163 S.C.). Nevertheless, it has been subsequently the O.L.C.C. ${ }^{7}$ the one which has set and determined the legitimization when the Constitution is silent (disputes of competence), as well as in the proceedings before the C.C. which were not foreseen in the Constitution.

Thus, while the amendment of the dispositions of the O.L.C.C. is relatively simple (organic laws are adopted, derogated and amended by an absolute majority, Section 81.2 S.C.), modifying the dispositions of the Constitution would imply modifying the Constitution itself (Sections 166 and subsequent), which, obviously, makes this possibility much more difficult.

However, apart from the Constitution and the O.L.C.C., it is also necessary to take into account the case-law itself of the C.C. It has contributed in an outstanding way to specifying the sense and the scope of the above mentioned rules. It can be said, besides, that in this particular case, our C.C. has shown, in general, an open and antiformalistic attitude, favouring the access to the Court, which, as our doctrine has highlighted, reinforces the fundamental right to the actual legal guardianship, established in Section 24 of the S.C. ${ }^{8}$

\section{RULES OF ACTIVE LEGITIMIZATION IN CONSTITUTIONAL ROCEEDINGS.}

\section{Individuals.}

In the Spanish system, the access of the individuals to the Constitutional jurisdiction is specially restricted. Apart from the case of the negative disputes of competence, which are very rarely used (see ad supra), the way for individuals to access the Constitutional jurisdiction is focused on the appeal for legal protection. Under Section 53.2 of the Constitution, any citizen can ask for the protection of particular rights foreseen in the Constitution itself through an appeal for legal protection before the C.C., and Section 162. 1. b), rules that "any individual or legal person standing for any legitimate interest is entitled to lodge an appeal for legal protection, as well as the Ombudsman or the General Attorney's Office".

In turn, the O.L.C.C. (Sections 41 and subsequent) has restricted the appeal for legal protection to the infringements of the rights arising from legal dispositions or actions carried out by the public powers (via de hecho). Therefore, it is not possible to lodge an appeal for legal protection against particular actions by individuals, although, in practice, the C.C. hears, in many occasions, the infringement of a fundamental right by an individual. What the C.C. usually does in such cases is to attribute the infringement

\footnotetext{
7 Section 162.2 S.C.: "For the rest of the cases, the organic law shall determine the legitimated persons and bodies".

8 See M. Sánchez Morón, "La legitimación activa en los procesos constitucionales”, Revista Española de Derecho Constitucional, nº. 9, 1983, pp. 10 y 11; and M. Aragón Reyes, "Artículo 162. Legitimación en los procesos constitucionales", in Comentarios a la Constitución Española de 1978, dir. O. Alzaga, vol. XII, Edersa, Madrid, 1999, p. 258.
} 
of the right to the legal body which did not remedy the damage, even if it should have done so.

Individuals cannot lodge appeals for legal protection against the laws or legislative decrees either. The possibility, actually real, that the content of a law itself infringes any of the fundamental rights to be protected, is solved in our system, through the so-called self-submission of unconstitutionality (autocuestión de inconstitucionalidad) (Section 55.2 O.L.C.C.): individuals lodge an appeal for protection against a case of application of a law and the C.C., after providing its protection, can assess the constitutionality of the law implied.

The appeal for legal protection can be lodged against actions of the legislature, the executive or the judiciary. In Section 46 of the O.L.C.C. it is foreseen, for the first case, that "the person directly affected" is entitled and, as for the two others, those who have been a party in the corresponding legal proceedings, since, in order to be entitled to lodge an appeal for legal protection before the C.C., it is necessary - except as regards the actions of the legislature, where it is possible to lodge a direct appeal for legal protection within three months from the effective date of the action in question - for the individual involved to have exhausted all the ordinary proceedings previously. The appeal for legal protection is therefore basically a subsidiary recourse: the C.C. will only act in case all the ordinary courts fail.

As we have seen, under the provisions of the Constitution, individuals must prove a "legitimate interest" in order to gain access to the Constitutional legal protection. This has been construed in a wide sense by the C.C. and, thus, the requirement of the O.L.C.C. as regards the appeals against actions of the executive and judiciary of having been a party in the corresponding legal proceeding, which appears to be a restriction on the legitimization provided in the Constitution, has also been understood in a flexible way. For the C.C. (S.C.C. $165 / 1987$, of $27^{\text {th }}$ October), on the one side, it is not enough to be a party in the legal proceeding, but it is also necessary to have "a legitimate interest in the protection of the Constitutional rights allegedly infringed"; and on the other side, (S.C.C. 4/1982, of $8^{\text {th }}$ February), even if an individual has not been a party in the previous legal proceeding, he/she is legitimated if "being obliged to be legally a party in the proceeding, he/she could not do it because of a reason not imputable to himself/herself".

In the same way, the fact that the O.L.C.C., in the appeals for legal protection against the legislature, mentions the "person directly affected", must not be understood as a restriction on the wider Constitutional principle of "legitimate interest". Therefore, this does not imply a requirement of "direct interest", this one being not so ample a concept as "legitimate interest".

Note, finally, that the requirement of exhausting the previous proceedings has also been subject to a wide and antiformalistic interpretation by the C.C.

To summarize the above, given the subject in question - protection and guarantee of the fundamental rights - , this general attitude, which favours the access to the appeal for legal protection (pro actione or favor actionis) in the C.C. is perfectly understandable. The dispositions of the O.L.C.C. on the legitimization of the appeal for 
legal protection have been construed under the Constitution, which, as we have already seen, interpreted this law in a wider sense.

\section{Political agents.}

In this section, I am going to focus only on the most significant and widely used Constitutional proceedings.

a) APPEAL FOR LEGAL PROTECTION. Apart from the individuals and the legal entities invoking a legitimate interest, the Constitution itself [Section 162. 1. b)] and the O.L.C.C. (Section 46.1) acknowledge that the Ombudsman and the General Attorney's Office are legitimated to lodge an appeal for legal protection. In these two cases, we are facing an objective legitimization, which can be explained from the perspective of the role both institutions play: the Ombudsman is responsible for the defence of the rights granted in Title I of the Constitution (Section 54 S.C.), and the task of the General Attorney's Office is promoting the action of the legal system for the defence of the legislation and the rights of the citizens (Section 124.1).

b) POSITIVE DISPUTES OF COMPETENCE. Within the framework of the disputes, the positive disputes of confidence between the State and the AA.CC. have been, by far, the ones which have proved more vitality in the recent years.

As regards this proceeding, the Constitution does not determine beforehand the subjects legitimated to lodge it. Thus it was the O.L.C.C. (Sections 62 and subsequent) which settled this point: the positive disputes of competence can be lodged both by the State Government as well as by the Governments of the AA.CC., against any disposition, resolution or action of the AA.CC. (as for the State Government) or the State or another A.C. (as for the Governments of the AA.CC.), provided that it is considered that the Constitutional competence system is infringed and within the period fixed 9 .

It must be highlighted, however, that the State Government and the Autonomous Governments do not enjoy an identical legal position:

i) The Autonomous Governments can only lodge a dispute when the disposition, resolution or action involved affects its own autonomy (Section 63.1 O.L.C.C.), this being a limit which is not set for the State Government. However, it is true that this restriction has not had any practical effective consequences.

ii) Whereas the State Government can lodge directly the positive dispute before the C.C. (within a period of two months), the Governments of the AA.CC. must (Section 63 O.L.C.C.) previously ask the State or the C.A. involved to derogate the disposition or to cancel the resolution or action in question (request of lack of competency). In this way, only if this attempt is not fruitful, the Autonomous Government can lodge the corresponding dispute before the C.C.

\footnotetext{
${ }^{9}$ Note that on this issue, the C.C., after some initial hesitancy has made it clear that the object of these conflicts does not include the legislative actions or decrees (C.C. 49/1984, of $5^{\text {th }}$ April).
} 
iii) On the other side, the State Government can urge the immediate suspension of the autonomous disposition or resolution involved for a period under five months (Section 64.2), whereas the Autonomous Governments can only ask for the suspension to the C.C. ("which shall be free to grant or refuse it". Section 64.3 O.L.C.C.).

c) UNCONSTITUTIONALITY APPEALS. Section 161.1 a) of the Constitution acknowledges that the C.C. has jurisdiction to hear unconstitutionality appeals against laws and legislative decrees. Later on, Section 162. 1 a) of the Constitution enumerates comprehensively and without making any distinction the subjects legitimated to lodge these unconstitutionally appeals, namely, the Prime Minister, the Ombudsman, fifty Deputes, fifty Senators, the collegiate executive bodies of the Autonomous Communities and their assemblies. However, the O.L.C.C. (Section 32) has developed this disposition in a restrictive way, as regards the legitimization of the bodies of the AA.CC., a fact that has led in turn some doctrinal sectors to question the constitutionality of this development ${ }^{10}$. Whereas the bodies or parts of the bodies of the State (the Prime Minister, the Ombudsman, fifty Deputes and fifty Senators) are generally legitimated to appeal against any law or legislative decree of the State or the AA.CC., the Governments and Assemblies of the AA.CC. are only legitimated to appeal against laws and legislative decrees of the State which might affect "their own autonomy".

The legitimization of the AA.CC. is thus restricted from two perspectives: on the one side, it is not possible to challenge the laws of other AA.CC., and, on the other side, within the scope of the State laws, they can only challenge those which "might affect their own autonomy"11. Nevertheless, note that the C.C., has construed in an increasingly wider and more open way the requirement of the impact on the autonomy of the AA.CC. So, in the words of the C.C., "the legitimization of the Autonomous Communities to lodge an unconstitutionally appeal is not aimed at claiming an infringed competence, but to purify the legal system and in this sense, this legitimization extends to all the cases where a natural link between the State Law and the competencies of the A.C. exists, which, in turn, can not be interpreted in a restrictive way ..." (S.C.C. $199 / 1987$, of $16^{\text {th }}$ December).

Lastly, note that the control of the constitutionality carried out by the S.C.C. is, apart from the case of the international treaties (Section 95 S.C.), a post factum control. As regards the unconstitutionally appeal, it is only possible to lodge it within three months from the issue of the law, disposition or legislative decree involved (Section 33.1

10 See, in this sense, J. Corcuera Atienza, "Autonomía y recurso de inconstitucionalidad (Legitimación de los órganos de las Comunidades Autónomas para interponer el recurso de inconstitucionalidad)", Revista Vasca de Administración Pública, no. 1, 1981, pp. 203 and subsequent; M. Sánchez Morón, "La legitimación...", ob. cit., pp. 15 and subsequent.; R. Canosa Usera, Legitimación autonómica en el proceso constitucional, Trivium, Madrid, 1992, pp. 93 and subsequent.; and E. García de Enterría and T.R. Fernández, Curso de Derecho Administrativo, vol. I, 9ª ed., Civitas, Madrid, 1999, pp. 164 and 165.

11 The restriction on the legitimization of the Autonomous Communities in this direct proceeding of Constitutional control, has been, without doubt, the most controversial issue as for the legitimization before the C.C. in Spain. 
O.L.C.C.) or, under exceptional circumstances, within nine months (Section 33.2 O.L.C.C. $)^{12}$.

\section{Courts}

We have already said that, even if the C.C. is the supreme interpreter of the Constitution and is the only body incumbent to control the constitutionality of the laws or legislative decrees, both judges and courts must also apply and interpret the Constitution. Judges and Courts are therefore incumbent to control the constitutionality of non legislative decrees (being obliged to restrain themselves from applying them if they are conflicting with the Constitution) and of all legal public and private actions (which will be null and void if they are conflicting with the Constitution). Even more so, when they apply a particular law in a proceeding, judges must try their constitutionality. But, if as a result of this judgment, they consider that the law infringes the Constitution, they must lodge before the C.C. a submission for unconstitutionality, since only the C.C. can rule on the unconstitutionality of legislative decree.

Under Section 163 of the Constitution ("when a legal body ..."), and Section 35.1 of the O.L.C.C. ("when a judge or court..."), any judge or court can lodge a submission for unconstitutionality before the C.C. They are thus the only subjects incumbent to legitimize in a proceeding. Something different is that, as Section 35.1 of the O.L.C.C. has already acknowledged, the submission might be lodged "by appointment or at the request of a party", since the ruling of the judge or court is never bound to the opinion or criteria of the parties.

Submissions for unconstitutionality can only be lodged "when a legal body considers, in the course of a given proceeding, that a law applicable to the case, on which the validity the ruling draws, might challenge the Constitution" (Section 163 S.C.). That is to say, two fundamental presuppositions must be met: firstly, it must be a disposition applicable to the legal proceeding in question, but besides, its validity or lack of validity (depending on the fact that it challenges or not the Constitution) must have relevant consequences on the ruling. As the C.C. itself points out, "the submission for unconstitutionality is not an action granted in order to challenge in a direct and abstract way the validity of laws, but an instrument provided to the legal bodies to reconcile the double requirement they face when they have to act abiding both by the law and the Constitution" (C.C. 17/1981, of $1^{\text {st }}$ June). In this sense, the legal body must "specify and justify to which extent the decision of the process depends on the validity of the disposition in question" (Section 35.2 O.L.C.C.). Secondly, the legal body must be hesitant as regards the constitutionality of the legal disposition; nevertheless, the doubt implied must be sufficiently supported and motivated: "the Judge cannot draw on the doubts the parties have raised concerning the constitutionality of the disposition; neither can the Judge just express his/her own doubts without giving the supporting reasons, since the parties in an ordinary process are not legitimated to lodge the

12 In principle, the O.L.C.C. (Section 79), established a procedure for the prior control of the proposals for organic laws. However, the repeated use of this proceeding, as a kind of suspensory veto, led to its abolition in 1985 (Section 79 was derogated by the Organic Law 4/1985, of $7^{\text {th }}$ June). 
submission before the Constitutional Court; neither the decision of the Constitutional Court is possible but as a response to the issues doubtful for the legal bodies, in a particular case, as regards the consistency between the Constitution and a legislative decree" (S.T.C . 17/1981, of $1^{\text {st }}$ June).

\section{SENSE AND CONSEQUENCES OF THE LEGITIMIZATION RULES DESCRIBED.}

The study of the sense or purpose of the different rules in force in Spain for the legitimization of Constitutional proceedings, as well as of the consequences or implications arising from them, cannot in my view be carried out in general way. Given the diversity of the Constitutional proceedings and, consequently, of the provisions for their legitimization, the most efficient way of analysis is, without any doubt, tackling this question from the approach of each one of these proceedings.

I will focus again on the most significant Constitutional proceedings.

a) UNCONSTITUTIONALITY APPEAL. In the systems with a concentrated Constitutional jurisdiction, it is usual that the legitimization to challenge a law before the C.C. is seen in a restrictive way. The 1978 Spanish Constitution is not an exception. As we have already said, all of the subjects legitimated to lodge appeals for unconstitutionality are Constitutional bodies or parts of Constitutional bodies, and thus, the possibility that individuals might challenge laws before the C.C. is excluded.

The legitimization in this proceeding is an abstract one: "the power to promote the unconstitutionality appeal is not conferred by the Constitution in order to meet a particular interest of those who are granted it, but under the high political qualification which is the result of its Constitutional task. By this appeal, no particular interest or right is defended, but the general interest and the supremacy of the Constitution" (S.C.C. $42 / 1985$, of $15^{\text {th }}$ March). However, it is evident that the legitimization of each one of these bodies is the result of different reasons and purposes.

The legitimization of the Prime Minister in this proceeding is reflected, in practice, by the fact of challenging the laws of the AA.CC., since in a Parliamentary Government arrangement, the underlying hypothesis is that laws are approved by the majority backing the Government in Parliament, and therefore, it is highly unlikely that the Parliament might challenge them. In this sense, the legitimization of the Prime Minister is aimed, above all, at making possible to monitor the constitutionality of the laws passed by the AA.CC.

The Constitutional acknowledgement of the legitimization of the Ombudsman can be understood as a kind of compensation for the fact that the individuals are not included amongst the legitimated parties. Let us remember that the task of the Ombudsman is, precisely, to defend the rights of the citizens. From this very same approach, it might be logical to understand that the legitimization of the Ombudsman would be restricted to the material scope of the protection of the fundamental rights. Nevertheless, it is true that the Ombudsman enjoys some acknowledged legitimization without any kind of limit or restriction (see S.C.C. 150/1990, of $4^{\text {th }}$ October). 
The grant of legitimacy to fifty Deputes (out of 350) or fifty Senators (out of 259 in this term) is a clear instrument aimed at protecting the minorities against the majority in the Parliament. They enjoy a privileged mechanism of reaction and control of the legislative resolutions adopted by a majority in the Parliament and, therefore, usually by the Government, which contributes to a great extent to the effective Constitutional control of the laws conferred on the C.C.

The legitimization of the AA.CC., particularly of their executive and legislative bodies, must be understood within the specific territorial organization of the State designed by the 1978 Constitution (Section 2 S.C.: "The Constitution is based on the indissoluble unity of the Spanish Nation, common and indivisible homeland of all the Spaniards, and acknowledges and guarantees the right to the autonomy of the nationalities and regions which compose it and the solidarity amongst all of them") ${ }^{13}$. This, amongst other things, results in a legitimization of the bodies of the AA.CC. to challenge State laws which might affect their own autonomy, although, as we have already seen, the C.C. has understood, in a progressive way, this last requirement in a really wide sense ("the Autonomous Community which challenges a State law is legitimated to act not only to defend its own jurisdiction in the matter, but also to purify the legal order it regulates, to the extent that the enforcement or deployment of the functions incumbent upon it might be affected". S.C.C. 1999/1987, of $16^{\text {th }}$ December).

In a decentralized system such as ours, it seems evident that the direct control of the constitutionality of the laws might have resulted very restricted if the AA.CC. would not have been granted the access to it. The autonomous legitimization in this field constitutes, in this way, an indispensable complement for the legitimization of the State bodies.

What has been excluded according to the O.L.C.C., as we have already seen, is the possibility for the Autonomous Governments and Parliaments to challenge the laws passed by other AA.CC. or, also, the laws passed by their own A.C. The first fact is explained, above all, to prevent the unconstitutionally appeal from becoming an element of continuous dispute and confrontation amongst the different AA.CC. The second fact might be due to a curious oversight during the processing of the O.L.C.C. in the Parliament. Nevertheless, note also that these restrictions on the autonomous legitimization can eventually be solved, to a great extent, by the different political links or the links at party level of the autonomous bodies with the central Government and the minorities in the Parliament.

Briefly, the rules of legitimization foreseen in this proceeding are open and plural enough to promote an effective control of the constitutionality of the laws and, therefore, to ensure the Constitutional primacy. However, note that the unconstitutionality appeal is subject to a deadline, after which it is not possible to challenge laws in this way any longer. As Jiménez Campo points out, this is a temporal

13 As regards this issue, note that our system of territorial distribution of powers is not reflected in the appointment of the magistrates of the C.C. (in whose election the AA.CC. do not take part) nor in the creation of the Constitutional jurisdictions within the AA.CC. On this general subject, see F. Tomás y Valiente, "Tribunal Constitucional de España", en Tribunales Constitucionales europeos y autonomías territoriales, S.C.C., Madrid, 1985, pp. 133 a 224. 
restriction "entirely coherent with the unconstitutionality appeal's political origin in our legal system, since the political-constitutional debate thus framed must have a deadline in order to safeguard the status of the law"14.

b) SUBMISSION OF UNCONSTITUTIONALITY. The guarantee of the subjection of the laws to the Constitution would only have a partial scope had the submission of unconstitutionality not been provided together with the unconstitutionally appeal. Indeed, this proceeding, open to both judges and courts, allows, as opposed to the appeal, to lodge submissions before the C.C., without any temporal limit, against any law applicable to a particular proceeding.

In the words of the C.C. itself, "the continuous purification of the legal system from the view of the constitutionality of the laws, and always apart of the action of the lawmakers themselves, is the result of a necessary cooperation between the bodies of the judiciary and the Constitutional Court, and only this cooperation can ensure that this task of purification is efficient and operates in a dynamic and not in a merely static way, since only by this means [the submission of unconstitutionality], and not through the unconstitutionality appeal, it is possible to take into account the effect the changing social reality operates on the content of the dispositions" (S.C.C. 17/1981, of $1^{\text {st }}$ June).

The legitimization of all judges and courts to lodge submissions of unconstitutionality before the C.C. encourages, in summary, a real and effective control of the constitutionality of the laws, since they are subject in this way to a continuous monitoring carried out by the judiciary. On the other side, the submission of unconstitutionality highlights the different position which, in our view, the judiciary and the C.C. enjoy. Only the C.C. is incumbent to rule on the unconstitutionality of a law, both judges and courts, on the contrary, being subject to it. This proceeding allows, in connection with the concurrent subjection of the judiciary to the Constitution, both judges and courts, in their respective roles of administrating the law (Section 117 S.C.), to solve the conflict arising between a law and the Constitution, forwarding the former to the C.C. so that it decides whether it conflicts or not with the Constitution.

c) POSITIVE DISPUTES OF COMPETENCE. In this proceeding, the C.C. acts as guarantor of the observance of the Constitutional system in the distribution of competencies of the non legislative decrees and the actions of the State and the AA.CC. Thus, if the disposition implied is a legislative decree, even if the unconstitutionality is based on competence issues, it is only possible to lodge an unconstitutionality appeal or a submission of unconstitutionality, as the case may be.

Disputes can be only lodged by the State Government or by an Autonomous Government. The executive assumes, in this way, a kind of representation, either of the State or of an C.A., since the dispute can be based, not only on the grounds of the dispositions or actions invading the competencies of the State or Autonomous Government (which is, of course, the typical case), but also on an invasion of the competencies by the rest of the bodies of the State or of the AA.CC.

14 F. Rubio Llorente y J. Jiménez Campo, Estudios sobre jurisdicción constitucional, McGrawHill, Madrid, 1998, p. 69. 
The legitimization of the executive of the State and the AA.CC., the true actors of the decentralization, cannot be questioned, in my view. Nevertheless, since only the executive is legitimized in this proceeding, it is easy to deduce that, sometimes, the submission or not of the dispute depends on the coincidence of the same political party in the different Governments, and not on the awareness of the infringement of the system of competencies.

Anyway, note that the fact that the case-law of the C.C. both on the disputes of competence and on the unconstitutionality appeals (the great majority of the appeals against autonomous laws lodged by the Prime Minister are based on issues of competence), has set and cleared a great many issues related to the complex procedure of consolidation of the "State of the Autonomies" (Estado de las Autonomías). Irrespectively of the several value judgments which this fact might arise, it is true that the contribution of the C.C. in this field can only be defined as fundamental.

To conclude, note the uneven procedural position of the subjects legitimated in this case (State-AA.CC.), although this fact is not justified for some people, it can be understood in the general framework of the measures of control of the State over the AA.CC. and, consequently, within the different and qualified Constitutional position of the State against the AA.CC.

d) APPEAL FOR LEGAL PROTECTION. In Spain, the fact that the C.C. is granted, by means of this proceeding, a role of guardianship and guarantor of the fundamental rights does not lack controversy, since this function might be fully assumed by the ordinary courts of justice. Besides, this is not a competence shared by all the models of concentrated Constitutional jurisdiction. In my view, however, this competence of the C.C., as García de Enterría points out, is perfectly justified, due to "the central position the fundamental rights occupy as regards the Constitutional construction and its set of values"15.

In fact, it must be said that this proceeding has enjoyed a clear social acceptance in Spain, its use has even surpassed all the expectations and, more importantly, this reinforced or extraordinary protection of the fundamental rights by the C.C. has contributed in an efficient way to the internalization and effective application of them in the framework of the general legal system (remember that Spain had just left Franco's regime and, consequently, its legal culture had been completely different to the one introduced by the Constitution).

Obviously, the wide legitimization granted as regards the appeals for legal protection, as well as the interpretation in favour of it generally made by the C.C., has been an essential source of the wide use of this proceeding. However, this also sets out the fact that, nowadays, some people question the need to amend it, since the appeal for legal protection surpasses at great length the capacity of our C.C. and provokes significant delays in the exercise of the rest of its tasks (currently, over 5,000 appeals for legal protection are lodged in the C.C. each year, and although a great majority are refused, given this figures, the two Chambers of the C.C. must hear, nevertheless, an

15 E. García de Enterría, La Constitución..., ob. cit., p. 142. 
extremely large number of cases) ${ }^{16}$. Thus, the doctrinal proposals to toughen the conditions to gain access to the appeal for legal protection abound. Nevertheless, these proposals have not usually been undertaken by the lawmakers ${ }^{17}$.Also note that, at this stage, many people assume that the normative and binding character of the fundamental rights is fully taken on by the judiciary, and therefore the formerly significant task carried out by the C.C. as regards this issues, would no longer be basic.

To conclude, we cannot finish without highlighting the significant implications of the fact that it is foreseen, within the framework of the appeal for legal protection, the possibility that the C.C. could eventually challenge itself for the constitutionality of the law whose application implied an infringement of rights. Indeed, individuals do not have, in Spain, the possibility to challenge a law directly, but they can obtain a ruling of the C.C. on its constitutionality through an appeal for legal protection against the application of the law involved. Anyway, it must be clearly stated that, irrespectively of the demands of the parties, the Chambers of the C.C. are the ones which can freely consider or not this self-submission, challenging, on the other side, the general character of justice on request of our system.

16 The C.C. is composed of two Chambers with six Magistrates each. The hearing of the appeals for legal protection corresponds, precisely, to the Chambers and not to plenary of the C.C. (Section 48 O.L.C.C.)

17 Indeed, there have been attempts to make the legal rulings on the infringement of the fundamental rights easier, with the aim of decreasing, in this way, the number of appeals. In this sense, the recent Law 1/2000 of Civil Procedure has foreseen a new kind of appeal for infringement of the fundamental right of actual legal guardianship (Sections 468 and subsequent.). 